\title{
Culture of needle biopsies of the liver from patients with suspected hepatitis
}

\author{
PATRICIA E. TAYLOR, A. J. ZUCKERMAN, AND L. J. FARROW \\ From the London School of Hygiene and Tropical Medicine and the West Middlesex Hospital, London
}

SYNOPSIS A technique is described for the culture in Leighton tubes of very small fragments of human adult liver obtained by needle biopsy. Most of the cultures were successful, and even after long storage proved to be as useful as those prepared from fresh suspensions. The diagnostic usefulness of the technique is already proved.

Attempts to grow differentiated human adult liver cells in tissue culture have met with many difficulties, and often they have proved unsuccessful (Gard and Alin, 1957). Bang and Warwick (1965) cultivated adult liver tissue from normal and hepatitis patients on a collagen substrate in roller tubes. Outgrowths consisted of a mixture of fibroblasts, macrophages, and cells which morphologically possessed the characteristics of parenchymal liver cells. Cole, Danks, and Campbell (1965), in attempting to isolate hepatitis virus from liver biopsy specimens of infants with neonatal jaundice, obtained fibroblastic outgrowths from pieces of tissue implanted in roller tubes.

Zuckerman, Tsiquaye, and Fulton (1967) described a method for obtaining monolayers of differentiated parenchymal human embryo liver cells in tissue culture. This technique has now been successfully modified and extended for the culture of very small fragments of human adult liver obtained by needle biopsy for diagnostic purposes.

\section{MATERIALS AND METHODS}

A total of 16 adult liver specimens obtained for diagnostic purposes from suspected cases of infectious and serum hepatitis were available for further examination. These were taken by percutaneous needle biopsy using a Menghini needle with a bore size of 1.4 or $1.6 \mathrm{~mm}$. The biopsy usually measured 2.5 to $4.0 \mathrm{~cm}$ in length. Half of the tissue was fixed in formol saline and later sectioned and stained for routine histological examination. The remaining portion of the specimen was placed under sterile conditions into cold medium 199 containing $0.2 \%$ sodium bicarbonate solution, 100 units $/ \mathrm{ml}$ penicillin, $100 \mu \mathrm{g} / \mathrm{ml}$ streptomycin, and 25 units $/ \mathrm{ml}$ nystatin, and transferred to the laboratory on melting ice. The

Received for publication 20th March 1969. specimen was kept at $4^{\circ} \mathrm{C}$ until cultured. Optimal results were obtained if the tissue were cultured immediately or as soon as possible after the specimen had been taken.

The fragment of liver was cut into pieces about $1.5 \mathrm{~mm}$. These were placed in a small vessel containing 1 to $2 \mathrm{ml}$ of freshly prepared $\mathbf{0 . 2} \%$ trypsin solution prewarmed to $37^{\circ} \mathrm{C}$, and allowed to stand at room temperature for 10 to 15 minutes. The pieces were gently swirled in the trypsin once or twice during this time. The softened pieces of tissue were washed in growth medium and teased with two sharp dissecting needles until a fine mash was obtained. Because of a tendency for the tissue to aggregate after trypsinization and teasing, it was resuspended in a minimal amount of growth medium, usually about $0.1 \mathrm{ml}$, without further washing. The growth medium was similar to that employed for the culture of human embryo liver cells (Zuckerman $e t$ al, 1967), but the amount of foetal calf serum was increased to $15 \%$.

Half of the teased tissue suspension was stored in liquid nitrogen at $-190^{\circ} \mathrm{C}$. A Union carbide BF-5 biological freezer was used for freezing. The approximate rate of cooling was $1.5^{\circ} \mathrm{C}$ per minute. One ml of growth medium containing $10 \%$ dimethyl sulphoxide was used initially as the suspending medium for freezing, but because of reports by Smith, Hadidian, and Mason (1967) and Perlman and Wolff (1968) that dimethyl sulphoxide may be hepatotoxic and is an inhibitor of liver alcohol dehydrogenase, $10 \%$ glycerol is currently being used. The method of recovery was similar to that described by Zuckerman, Kay, and Hockley (1968) for human embryo liver cells.

The remaining half of the tissue suspension was implanted on polythene discs using clotted mouse plasma as an adhesive (Zuckerman et al, 1967). Because of the small amount of tissue available, usually only six to eight small separation cultures were obtained. The implants were transferred into tissue culture plates and incubated at $35^{\circ} \mathrm{C}$ in a humidified dessicator containing $2 \%$ added $\mathrm{CO}_{2}$. After eight to 10 days, the discs were removed and placed with the cell surface upwards 
FIG. 1. Leighton tube viewed from above. (Reproduced from 'Virus diseases of the liver' by A. J. Zuckerman by courtesy of Butterworths, London.)
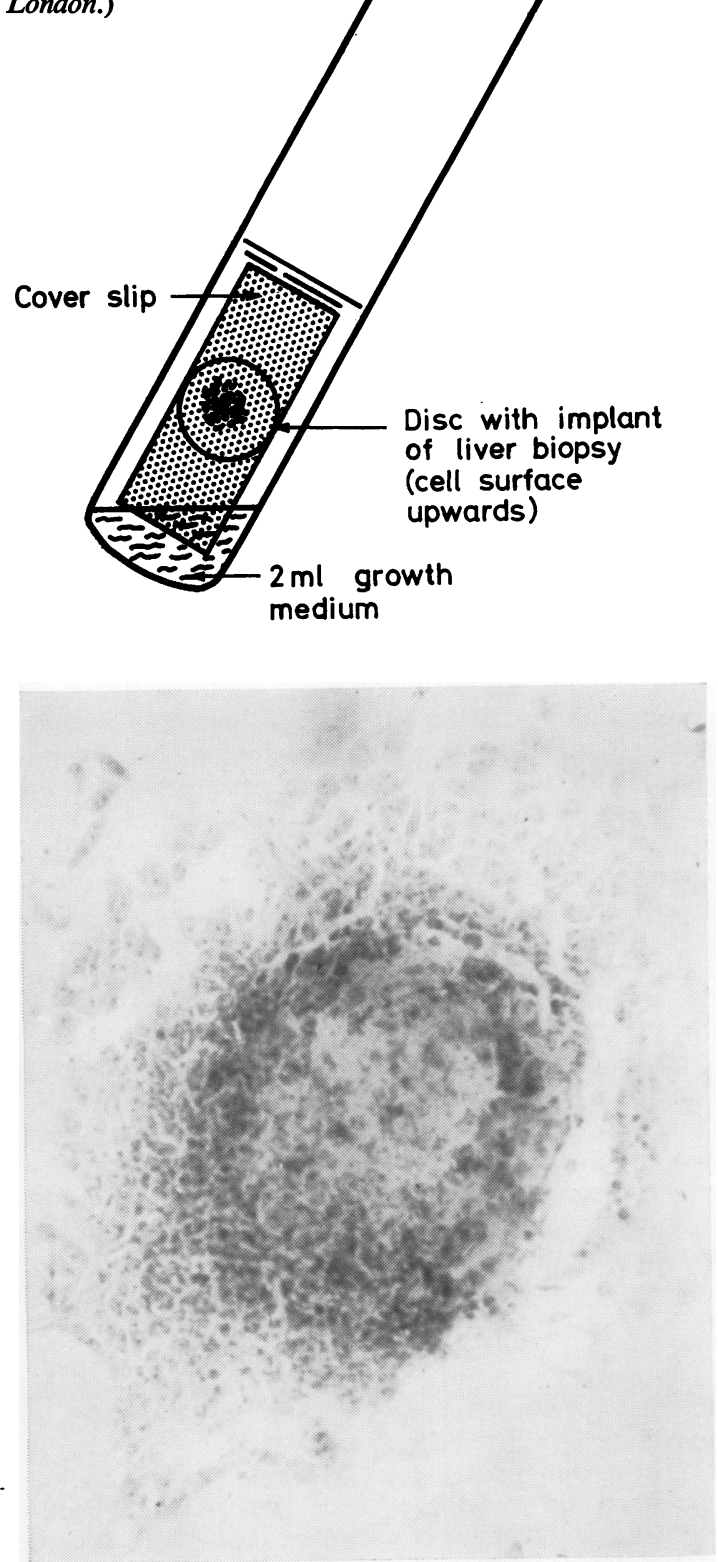

FIG. 2 .

FIG. 2. Adult liver biopsy 16 days after implantation of teased tissue. The cells growing from the edges of the biopsy consist mainly of polygonal-shaped, epithelial-like cells. A number of spindle-shaped cells are also present, mainly at the periphery of the culture. $\times 280$.

FIG. 3. Part of the monolayer of hepatic cells obtained from an adult liver biopsy after 16 days in culture. $\times 450$. on sterile coverslips which were then inserted into Leighton tubes. One and a half $\mathrm{ml}$ of fresh growth medium was added to each tube. The disc remained immersed in the growth medium (Fig. 1). By inverting the tube, the disc adhered to the coverslip on the flat side of the tube, and could be examined at frequent intervals by light and phase-contrast microscopy.

\section{RESULTS}

Successful cultures were obtained from 12 specimens of adult liver tissue. One failed to grow, and three were preserved in liquid nitrogen only. Usually, $\overrightarrow{0}$ cells grew out on 30 to $60 \%$ of the discs from $N$ successful cultures. Both polygonal shaped epithelial- $\stackrel{N}{\circ}$ like cells as well as spindle-shaped cells grew out from the minute fragments of teased-out tissue and spread to form a monolayer of cells. Essentially 윽 two types of cells could be readily distinguished, $\rightarrow$ hepatocytes and fibroblast-like cells. Often there $z$ was a predominance of hepatocytes (Figs. 2 and 3). The hepatocytes were frequently binucleated, and 3 their cytoplasm appeared granular and foamy. The $\Phi$ fibroblasts were typically spindle shaped. No specific

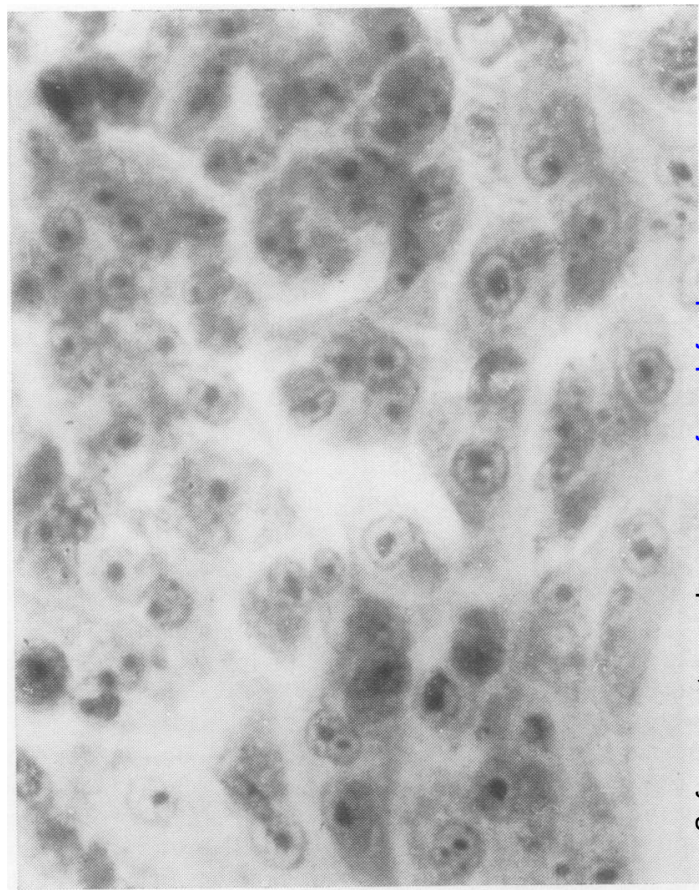

FIG. 3 . 
cytopathic changes have developed so far in any of the cultures.

Preliminary examination of cultured liver biopsy material by electron microscopy revealed the presence of several cell types whose ultrastructural features resemble hepatocytes, fibroblasts, and Kupffer cells. Glycogen particles were seen within the hepatocytes.

To date, two specimens have been successfully recovered from liquid nitrogen after being stored for 25 days and $\mathbf{4 8}$ days respectively. Both resulted in cultures that were similar to those that were obtained from freshly prepared suspensions. The first was preserved in $10 \%$ dimethylsulphoxide and the second in $10 \%$ glycerol. The remaining specimens are being kept at $-190^{\circ} \mathrm{C}$ for long-term storage and other studies.

\section{COMMENT}

Disaggregation of tissue by trypsinization as described by Zuckerman et al (1967) for the cultivation of human embryo liver cells is impracticable for the very small fragments of adult liver tissue obtained by needle biopsy. Limited contact with trypsin followed by teasing provides an efficient method for processing such specimens. Cultures of differentiated liver cells were consistently obtained. It is also conceivable that this method would prove successful when applied to the culture in vitro of cells from biopsies of other tissues, especially those that have been found difficult to culture by con- ventional methods. The use of Leighton tubes for repeated examination of the separation cultures overcomes a technical limitation previously associated with cultivation in the tissue culture plates as described for embryo liver cells.

The extension of tissue culture techniques to the routine examination of liver biopsy material offers interesting possibilities for future studies. It may well find application, in due course, in clinical pathology and medicine (Weinbren and Zuckerman, 1967). The study of the ultrastructural features of the cells by electron microscopy and its correlation with clinical findings is but one important aspect of the work currently being undertaken.

This work was supported by a generous grant from the Medical Research Council.

\section{REFERENCES}

Bang, F. B., and Warwick, A. C. (1965). In Cells and Tissues in Culture, edited by E. N. Willmer, vol. 2, p. 624. Academic Press, New York and London.

Cole, R. A., Danks, D. M., and Campbell, P. E. (1965). Lancet, 1, 1368.

Gard, S., and Alin, K. (1957). In Hepatitis Frontiers (Henry Ford Hospital International Symposium, 1956), edited by F. W. Hartman, G. A. LoGrippo, J. G. Mateer, and J. Barron, p. 169. Churchill, London.

Perlman, R. L., and Wolff, J. (1968). Science, 160, 317.

Smith, E. R., Hadidian, E., and Mason, M. M. (1967). Ann. N.Y. Acad. Sci., 141, 96.

Weinbren, K., and Zuckerman, A. J. (1967). In The Liver, edited by A. E. Read, p. 55. Butterworth, London.

Zuckerman, A. J., Kay, H. E. M., and Hockley, A. B. (1968). J. clin. Path., 21, 109.

-, Tsiquaye, K. N., and Fulton, F. (1967). Brit. J. exp. Path., 48, 20. 